研

究

$$
\mathrm{Mg}-\mathrm{Be} \text { のメカニカルアロイング }
$$

\author{
小林 慶三, 西尾 敏幸, 杉山 明, 松本 章宏, 尾崎 公洋 \\ 名古屋工業技術研究所，干 462-8510 名古屋市北区平手町 1-1.
}

\title{
Mechanical Alloying of $\mathrm{Mg}-\mathrm{Be}$
}

\author{
Keizo Kobayashi, Toshiyuki Nishio, Akira Sugiyama, Akihiro Matsumoto and Kimihiro Ozaki \\ National Industrial Research Institute of Nagoya, AIST, MITI, 1-1 Hirate-cho Kita-ku, Nagoya 462-8510.
}

Received February 15, 2000

\begin{abstract}
SYNOPSIS
$\mathrm{Mg}-10$ mass $\% \mathrm{Be}, \mathrm{Mg}-20$ mass $\% \mathrm{Be}, \mathrm{Mg}-30$ mass $\% \mathrm{Be}$ and $\mathrm{Mg}-40$ mass $\% \mathrm{Be}$ alloys were synthesized by mechanical alloying (MA) of elementary $\mathrm{Mg}$ and Be powders for $720 \mathrm{ks}$ milling under $66 \mathrm{kPa}$ argon gas atmosphere using by a planetary ball milling. In the case of $\mathrm{Mg}-10$ mass \% Be, the big blocks occurred due to the joining of the MA powders. Others showed fine powders after the MA process. Mg was able to compound 10 mass\% $\mathrm{Be}$ by the MA process safely. In the obtained $\mathrm{Mg}-10$ mass\% Be block, Be particles dispersed in the $\mathrm{Mg}$ matrix uniformly and had no reaction with $\mathrm{Mg}$.

$\mathrm{Mg}-10$ mass\% $\mathrm{Be}$ alloy synthesized by the MA was consolidated by pulsed current sintering at $673 \mathrm{~K}$ for $0.5 \mathrm{ks}$ under a pressure of $196 \mathrm{MPa}$. The sintered body was a composite material including homogeneous $\mathrm{Be}$ particles and showed a hardness of $68 \mathrm{HV}$.
\end{abstract}

KEY WORDS

magnesium, beryllium, mechanical alloying, pulsed current sintering, composite

\section{1 緒訔}

マグネシウムは実用金属材料の中で最も軽量な材料であ乃. そのため, 環境負荷の小さなリサイクル性に富む材料として 電気部品や自動車部品の分野での利用が拡大されている. し かし，マグネシウムは結晶構造が hcp であるため加工性が悪 いうえに，実用材料としては強度や硬度が低いという問題が 存在している. マグネシウムの強度を改善する方法として, 複合化が考えられてきている。これまでに, Feを分散した複 合材料)やSiCを分散させた複合材料23)が報告されているが, これらの分散粒子はいずれもマグネシウムよりかなり重い材 料であり，マグネシウムの有する軽量性を損なっている。 そ こで,マグネシウムの軽量性を損なわない分散粒子として Be 粉末について検討することにした. ただ, Beは酸化すると毒 性を示すことから，その取り扱いには十分な注意が必要であ る. $\mathrm{Mg}$ と Be は融点差が大きいため, 溶解による複合化は難 しい. また，粉末冶金的な手法による合金化においても，Be が微細になれは酸化は容易に進行することから，危険性は增 加する.
$\mathrm{Mg}$ 粉末と Fe粉末をメカニカルアロイング(以下, MAと略 す) 法で合金化すると， Feの添加量によって Fe粉末が均一に 分散したバルク状の複合材料が得られることを報告1)した。 これは, $\mathrm{Mg}$ と Fe が相互に固溶しない合金系であるために生 じた現象であろうと考えられる. Beも $\mathrm{Fe}$ と同梯に, $\mathrm{Mg}$ との 相互固溶はほとんどない元素である.そこで, Mg と Beを MA によって合金化すれば, $\mathrm{Mg}$ 中に Be 粉末が均一に分散したバ ルク状の複合材料が得られる可能性が高い，このようなプロ セスでの複合化は，溶解法による合金化よりはるかに安全で あろうと考えられる。

\section{2 実験方法}

出発原料として $\mathrm{Mg}$ 粉末 ( $99 \mathrm{mass} \% \mathrm{Mg}$ ) および Be 粉末 (99mass\%Be) を用い, Mg-10mass\%Be, Mg-20mass\%Be, Mg30mass\%Be および Mg-40mass\%Be 組成になるように科量し， 振動型ボールミル(日新技研製スーパーミスニ)によるMA処 理を行った. MAの容器(80ml) にはステンレス鋼 (SUS304)製 のものを用い，10申のボールにはクロム鋼 $(\mathrm{Fe}, 11 \mathrm{mass} \% \mathrm{Cr}$, 
$1.4 \mathrm{mass} \% \mathrm{C}, 0.8 \mathrm{mass} \% \mathrm{Mo}, 0.6 \mathrm{mass} \% \mathrm{Mn}, 0.4 \mathrm{mass} \% \mathrm{Si}$ ) 製のもの を用いた. MAはおよそ $66 \mathrm{kPa}$ の減圧アルゴンガス雾囲気中に て, 最長 $720 \mathrm{ks}$ 間の処理を行った. 1 回に配合した粉末の重量 はボール総重量の5\%とした. 得られた粉末について, 目視に よる外観観察，X線回折による構成相の同定を行った.

さらに, MA 粉末をパルス通電焼結装置 (イスミテック製 SPS-510L)により固化成形を行った. 固化成形は, 内径 $10 \mathrm{~mm}$ で外径 30mm の超硬製の型を用いて，673Kにて 0.3ks 間保持 することにより固化成形を試みた. なお, 成形は196MPaの加 圧下にて行い, 成形時の温度は超硬製の型に $3 \mathrm{~mm}$ 程度挿入し た $\mathrm{K}$ 型熱電対により測定した. 得られた成形体について $\mathrm{X}$ 線回 折による構成相の同定, 光学顕微鏡による組織観察を行った.

\section{3 実験結果および考察}

3.1 Mg-Be のメカニカルアロイング

$720 \mathrm{ks}$ 間の MA 処理を行った $\mathrm{Mg}-\mathrm{Be}$ 合金粉末の外観写真を Fig.1 に示す. Mg-10mass\%Be 組成においては, $\mathrm{Mg}-\mathrm{Fe}$ 合金の 場合 ${ }^{1)}$ と同様にバルク状の塊が生成していた。しかし，MA合 金中の Be 量が増加すると, 塊と微細な粉末が混在するように なり, Mg-30mass\%Beより Be 含有量の多い合金では微細な粉 末しか得られなかった. Beは微粉化すると容易に表面が酸化 するものと考えられ，Mg-30mass\%Be および Mg-40mass\%Be 合金はその取り扱いが難しいものと考えられる. また， Mg20 mass\%Be合金粉末のように微粉と塊が混在している材料も, Be がすべて塊の内部に存在しているとは考えられないので， 全体が微粉となった合金と同じく危険な材料であると考えら れる.したがって, Be をすべて塊の中に捕捉している $\mathrm{Mg}-$ 10mass\%Beのみが本プロセスにおいて安全に合金を作成でき る合金組成であることがわかった。

Mg-10mass\%Be 合金でみられる塊がどのようなプロセスで 形成されるのかは興味深い，そこで，Mg-10mass\%Be 組成の
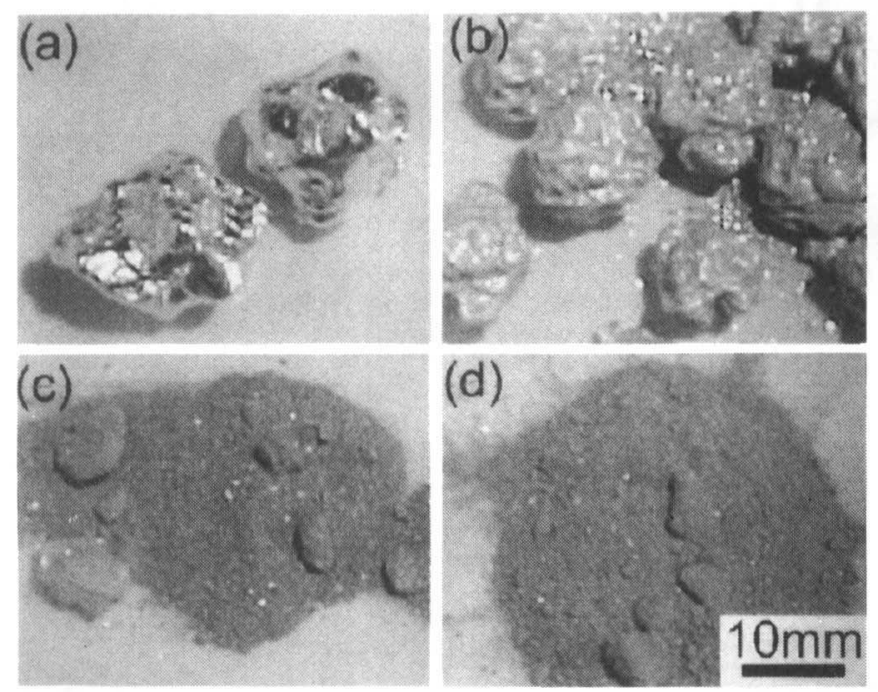

Fig.1 Appearance photography of mechanically alloyed (a) $\mathrm{Mg}$ 10 mass $\% \mathrm{Be}$, (b) $\mathrm{Mg}-20$ mass $\% \mathrm{Be}$, (c) $\mathrm{Mg}-30$ mass $\% \mathrm{Be}$ and (d) $\mathrm{Mg}-40$ mass $\%$ Be powders after milling for $720 \mathrm{ks}$.
混合粉末をMAにより種々の時間処理を行い，得られた粉末 (塊)の外観を観察した. 90ks, 180ks, 360ks および 540ks 間の MA 処理を施した Mg-10mass\%Be 合金の外観を Fig.2 に示す. 多量の Mg を含んでいるため, MAの初期段階 $(90 \mathrm{ks})$ において は扁平なティスク状の塊が生成していることがわかる.これ は, $\mathrm{Mg}$ の軟らかさと耐くほみ性の良さからこのような変形 1 (,4) が生じたものと考えられる. また, さらに MAを続けると. ティスク状の粉末がそれぞれ圧着されて, 大きなディスク状 の粉末へと変化している. 本来 MAで導入される機械的なエ ネルギーによって塊は破砕されるはずであるが，本合金では 機械的なエネルギーによって圧着されている．また，分散粒 子である Beは多量に含まれていると破壊の起点になり，微粉 化を促進するものと考えられるが，10mass\% Be 程度では $\mathrm{Mg}$ の性質が支配的であり, 粉砕にいたらなかったものと考えら れる.さらに, MAを続けると, 360ks から 540ks の MA 処理 によってティスク状の塊の周囲が変形され, 球形の塊へと変 化している. 90ksのMAで得られたディスク状の塊は $180 \mathrm{ks} の$ MAによりその数が明らかに減少している。これは, 90ksで 得られたティスク状の塊が相互に圧着して大きなディスク状 の塊が形成されたことを示している. しかし，それ以上の時 間の MA では, 塊の数にはほとんど変化がなく, MAボール の衝突によってディスク状の塊の周辺部が変形しているだけ と考えられる. 本実験のように $10 \phi$ のボールを用いた MA で は, $180 \mathrm{ks}$ 間の処理で得られた約 $10 \mathrm{~mm} \phi$ のティスク状の塊が 安定な大きさであろうと考えられる.MAで形成された塊の 大きさを変えるには, MAボールの大きさを変えることが有 効であろうと考えられる.

Mgは長時間のMA処理を行っても粉末が作製できず, ティィ スク状あるいは平板状の塊しか得ることができない.しかし， Mg-10mass\%Be組成では長時間のMAで球状の変形が生じた. これは, $10 \mathrm{mass} \% \mathrm{Be}$ という Beの添加が塊状の MA 粉末にある 程度の硬さと剛性を与え, その結果として周辺部が変形して
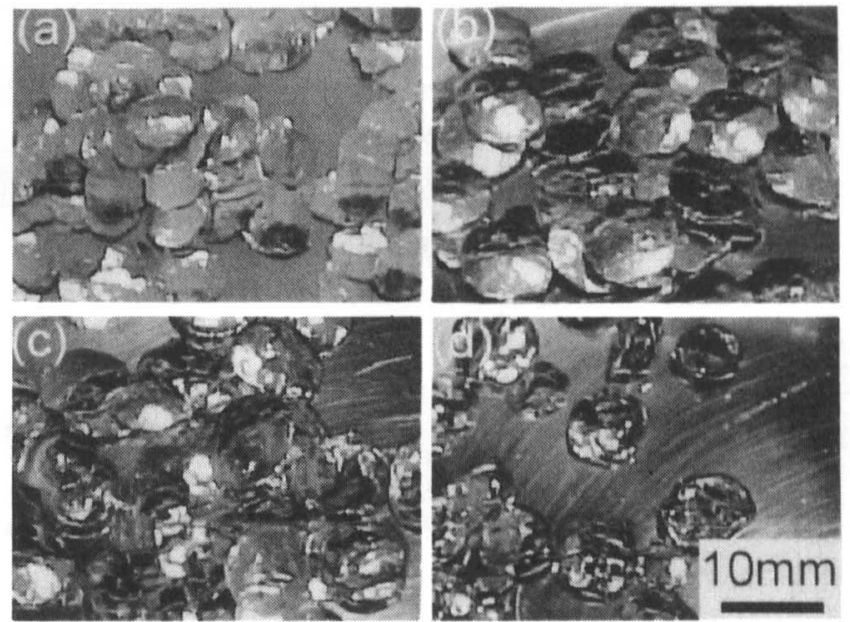

Fig.2 Appearance photography of mechanically alloyed $\mathrm{Mg}$ 10 mass \% Be powder after milling for (a) $90 \mathrm{ks}$, (b) $180 \mathrm{ks}$, (c) $360 \mathrm{ks}$ and (d) $540 \mathrm{ks}$. 
球状になったものと考えられる.球状になった MA 粉末は安 定であり,それ以上の変形あるいは粉砕は生じなかった.MA 時間に伴う塊状の MA粉末の厚み変化を Fig.3に示す. MAの こく初期においてティスク状の粉末が形成され，このティス ク状粉末が急速に球状化していることがわかる.

720ks間のMAでみられた塊状の MA粉末は上述のようなプ ロセスで形成されたものと考えられる.この形成プロセスを 確認するため,得られた塊状のMA粉末の断面を観察した.考 案した形成プロセスが正しければ, 塊の中には孔が含まれて いる可能性が高く, 球状の塊の表面と内部では結晶構造に差 異が生じているはずである.すなわち, MAで得られた塊の表 面は $\mathrm{Mg}$ のすべり変形が生じたことを示しており，内部はほ とんど変形をしていないX線回折パターンを示すものと考え られる. そこで, 720ks 間の MAで得られた塊を切断して断面 の観察を行った結果を Fig.4に示す. 塊の内部には空孔が存在 していることが確認できた。したがって，ティスク状の粉末 が360ks 以上の MAで球状化したことが裏付けられる.また, 塊には多くの亀裂が存在しており, 球状化する前の粉末は多 くのティスク状の粉末が圧着された状態であることも確認で

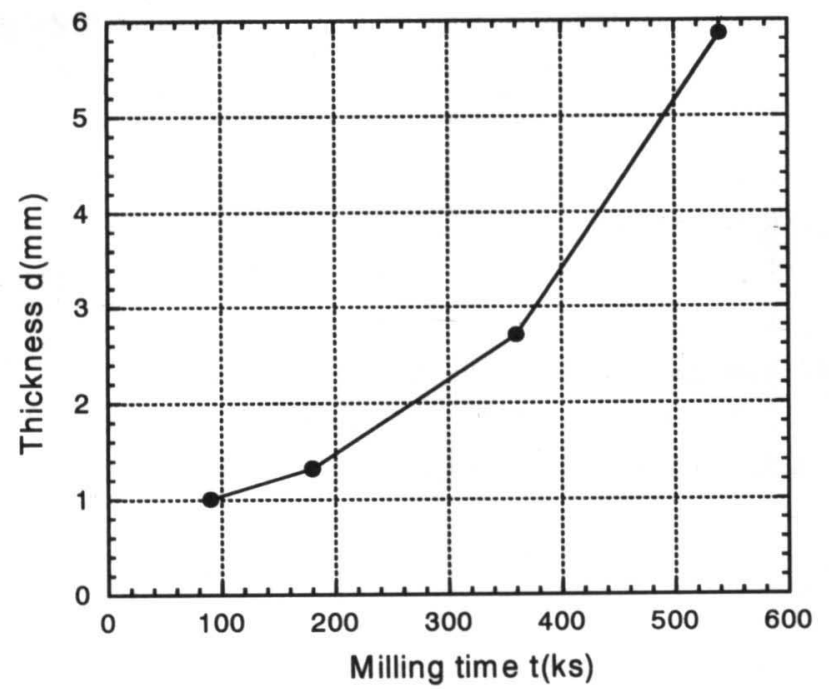

Fig.3 Thickness of mechanically alloyed $\mathrm{Mg}-10$ mass\% $\%$ Be powders plotted against milling time.

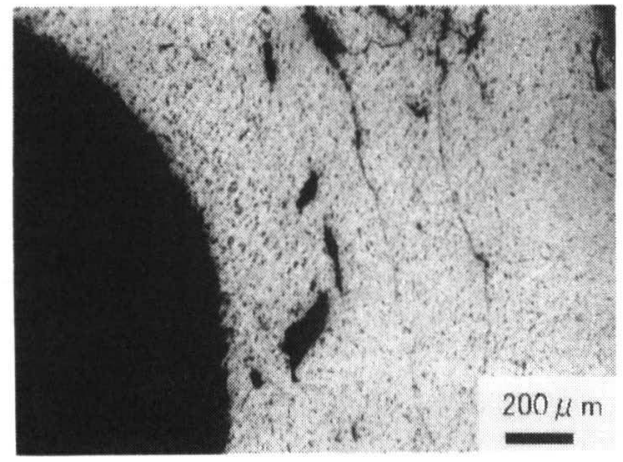

Fig.4 Microstructure in cross section of mechanically alloyed Mg10 mass\% Be block after milling for $720 \mathrm{ks}$.
きた. ただ，塊状の MA粉末は $\mathrm{Mg}$ マトリックス中に細かな Be 粒子が均一に分散していることから，MAのこく初期段階(90ks 未満のMA)でBe粉末がMg中に分散していたものと考えられる.

塊状の MA粉末の表面および削りこんだ断面でのX線回折 パターンを Fig.5に示す. MA 粉末表面は $\mathrm{Mg}$ 圧延材料と同様に (002)面のピークが強くなっている.これは, ティスク状粉末 の表面の X線回折パターンと同じであり，ティスク状になっ た MA粉末がカールして球状の塊を形成したことがわかる. また, 断面でのX線回折パターンは標準の $\mathrm{Mg}$ の X線回折パター ンを示しており,大きな変形が生じていないものと考えられる. 3.2 MA で合成した $\mathrm{Mg}-\mathrm{Be}$ 合金のパルス通電焼結

720ks 間の MA で塊状になった Mg-10mass\%Be 合金を内径 $10 \mathrm{~mm}$, 外形 $30 \mathrm{~mm}$ の超硬製の型内にいれ，196MPa の加圧下 にて $673 \mathrm{~K} て ゙ 0.3 \mathrm{ks}$ 間保持することにより変形を行った. 得ら れた成形体の外観を Fig.6に示す. Mg-10mass\%Be合金は割れ を生ずることなく, 変形をすることができた. また, MA時に 生成した塊内部の空孔も成形体には残存しておらず, スムー スな変形か行えたものと考えられる. 得られた成形体の光学 顕微鏡組織を Fig.7に示す. 濃い色の部分が Beである. Beが

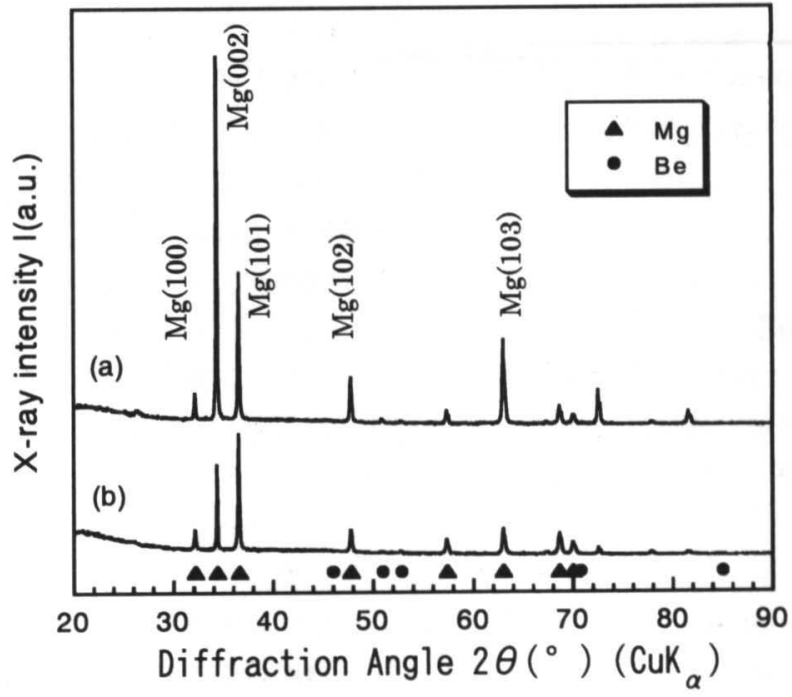

Fig.5 X-ray diffraction patterns of (a) surface and (b) inner side of mechanically alloyed $\mathrm{Mg}-10$ mass\% $\%$ block after milling for $720 \mathrm{ks}$.

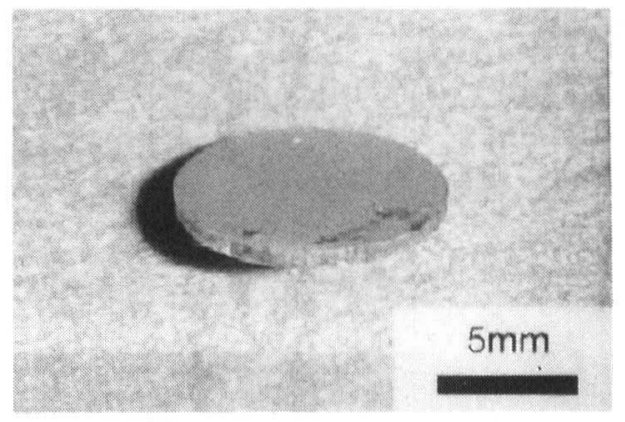

Fig.6 Appearance photography of sintered Mg-10mass\%Be at 673 $\mathrm{K}$ for $0.3 \mathrm{ks}$ under a pressure of $196 \mathrm{MPa}$. 
均一に Mg マトリックス中に分散している様子がわかる。ま た,この組織を画像解析してみると, ほほ配合組成の Beが含 まれていることが確認できた．この成形体の硬度を $50 \mathrm{~g}$ の荷 重下で測定すると, $68 \mathrm{HV}$ の硬さを示した.これは, $\mathrm{Mg}$ の硬 度の 1.5 倍以上であり, MA で合成した粉末に含まれる Be が 增加すると成形体の硬度は上昇し, $\mathrm{Mg}-40 \mathrm{mass} \% \mathrm{Be}$ 合金を同 じ条件で成形するとその硬度は $148 \mathrm{HV}$ になった。

パルス通電焼結した Mg-10mass\%Be 合金のX線回折パター ンおよび同じ条件で合成した $\mathrm{Mg}-40 \mathrm{mass} \% \mathrm{Be}$ 合金の X 線回折 パターンを Fig.8に示す. Mg-10mass\%Beではディスク状の粉 末が形成されたのちに塊状の粉末が得られ，その粉末がパル ス通電焼結で変形しているため, 成形体の $\mathbf{X}$ 線回折パターン は塊状の MA 粉末と同様に Mgの(002) が強くなっている.ま た, $\mathrm{Mg}$ のピーク位置は変化しておらず, 成形過程においても $\mathrm{Mg}$ と $\mathrm{Be}$ の反応は生じていないものと考えられる.また, $\mathrm{Mg}-$ 40mass\%Beでは, MA 粉末が微粉末であったため, Mgの変形 が生じておらず, 成形体の X 線回折パターンも $\mathrm{Mg}$ の標準的 な強度になっている. また, $\mathrm{Mg}-40 \mathrm{mass} \% \mathrm{Be}$ 合金においても $\mathrm{Mg}$ と $\mathrm{Be}$ のピークはシフトしておらず, $\mathrm{Mg}$ と $\mathrm{Be}$ の反応は生 じていないものと考えられる.

$\mathrm{Mg}$ 粉末と $\mathrm{Be}$ 粉末を出発原料として, MA 法で Mg$10 \mathrm{mass} \% \mathrm{Be}$ 合金を合成すると, 粉末が形成されず塊状の複合 材料が作製できた.この方法では粉末が全く作製されないこ とから, 安全な $\mathrm{Mg}$ 基複合材料の作製方法と考えられる.ま た，得られた複合材料はパルス通電焼結によって容易に成形 できることから様々な工業製品形状へ加工することが可能で あり, 得られた成形体も $\mathrm{Mg}$ マトリックス中に Be粒子が均一 に分散した複合材料であった．本プロセスで，安全に $\mathrm{Mg}-\mathrm{Be}$ 合金を成形するためには合金組成が大きな影響を与えること が明らかとなった。

$$
4 \text { ま と }
$$

$\mathrm{Mg}$ 粉末と Be粉末を出発原料として MA処理により Mg-Be 合金を合成した.さらに得られた MA粉末をパルス通電焼結 により固化成形することを試みた. その結果，以下に示す結 論が得られた。

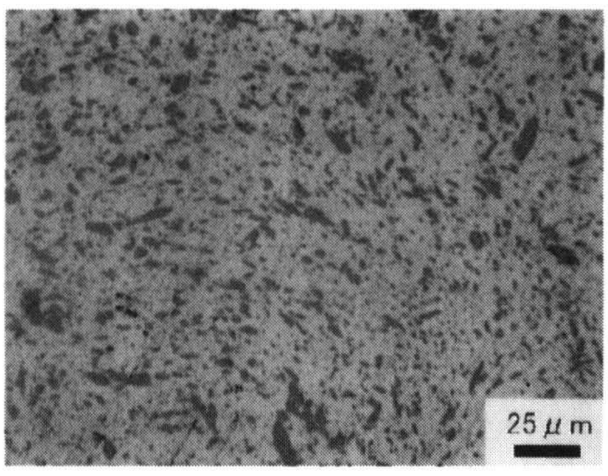

Fig.7 Microstructure of sintered $\mathrm{Mg}-10$ mass $\% \mathrm{Be}$ at $673 \mathrm{~K}$ for 0.3 ks under a pressure of $196 \mathrm{MPa}$.
(1) Mg粉末とBe粉末を出発原料として MA法で合成した Mg$\mathrm{Be}$ 合金は, Be 量によって得られる粉末の形状が異なる. Mg-10mass\%Be では 720ks 間の MA で塊状の粉末が得ら れ, Be 量が増加するにしたがった粉末が増加する. 粉末 の増加は, $\mathrm{Be}$ の酸化を容易にするため, 取り扱い上, 危 険と考えられる。

(2) Mg-10mass\%Beは，ティスク状の粉末が合成されたのち, 粉末どうしの圧着が生じ，その後球状化する. そのため, MAで得られた塊状の粉末の内部には空孔が残存し, 塊の 表面には圧延と同じ変形が観察される.

(3) MA で合成した Mg-10mass\%Be 合金の塊は，196MPaにて 673Kパルス通電焼結により成形することができる．得ら れた成形体は $\mathrm{Mg}$ マトリックス中に Be 粒子が均一に分散 した複合材料である. 複合材料の硬度は Be 量によって変 化し, Mg-10mass\%Beでは 68HVである.

\section{文献}

1) 小林慶三, 尾崎公洋, 杉山明, 西尾敏幸: "Mg-Feのメカ二 カルアロイングによる合成 ", 粉体および粉末治金, 46 (1999)1068-1072.

2) 金埃洙,金子純一,菅又信: "SiCウィスカー/AZ91Dマグネ シウム合金および SiCウィスカー/2324アルミニウム合金 複合材料の高温変形挙動 ", 日本金属学会誌, 56(1992)819827.

3) K.Wu, M.Zheng, MZhao and C.Yao: "Interfacial Reaction in Squeeze Cast SiCw/AZ91 Magnesium Alloy Composite", Scripta Materialia, 35(1996)529-534.

4) 尾崎公洋, 小林慶三, 西尾敏幸: "メカニカルアロイングに よる $\mathrm{Fe}-\mathrm{Mg}$ 合金の作製とパルス通電焼結による固化成形", 名古屋工業技術研究所報告, 45(1997)631-638.

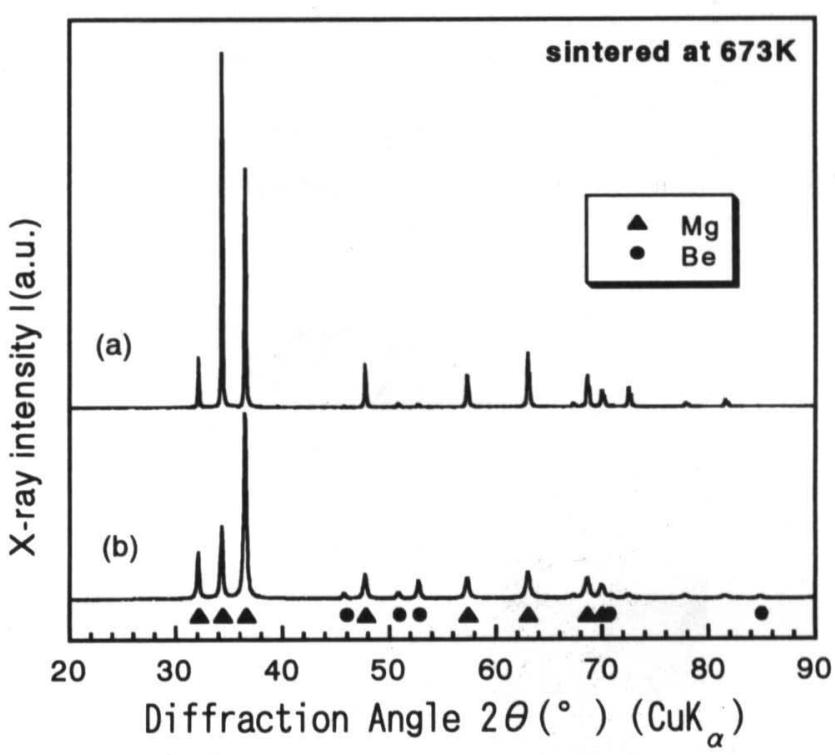

Fig.8 X-ray diffraction patterns of sintered (a) $\mathrm{Mg}-10 \mathrm{mass} \% \mathrm{Be}$ and (b) $\mathrm{Mg}-40$ mass $\% \mathrm{Be}$ at $673 \mathrm{~K}$ using mechanically alloyed powders after milling for $720 \mathrm{ks}$. 